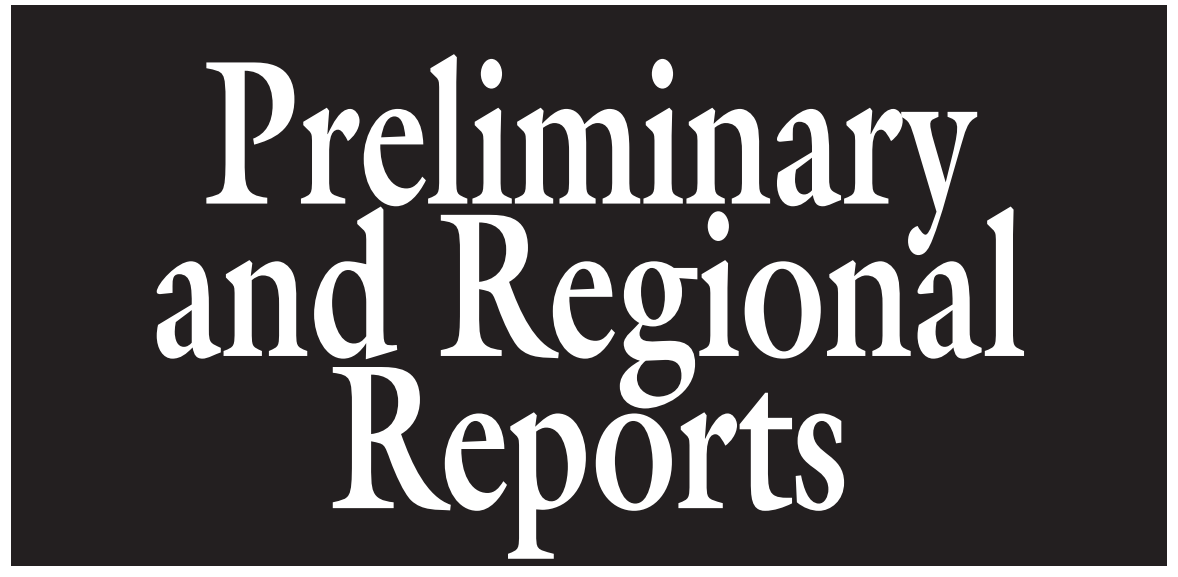

\title{
Strawberry Cultivar Injury After Two Contrasting Minnesota Winters
}

\author{
Shengrui Yao ${ }^{1,2,4}$, James J. Luby ${ }^{1}$, and David K. Wildung ${ }^{2,3}$
}

AdDITIONAL INDEX wORDs. Fragaria $\times$ ananassa, cold hardiness, winter survival

SUMMARY. As part of our hardy strawberry (Fragaria $\times$ ananassa) breeding program, winter hardiness of 15 strawberry cultivars was evaluated in the field after Winter 2005-2006 and a test Winter 2006-2007 with no snow cover at Grand Rapids, MN. After the snow-covered Winter 2005-2006, plant stand (percent leaf coverage for the designated area for each plot) increased for all cultivars in the mulched treatment and some cultivars in the unmulched treatment with slight decreases only for several cultivars in the unmulched treatment. However, after Winter 20062007, the plant stands of all cultivars drastically decreased in both mulched and unmulched treatments. 'Clancy', 'Evangeline', and 'L'Amour' were the three most

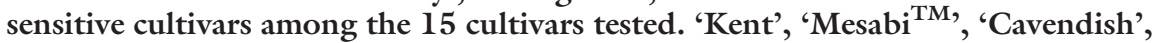
and 'Brunswick' were the highest yielding cultivars for both 2006 and 2007 in the mulched treatment. In the unmulched treatment, 'Brunswick', 'Mesabi ${ }^{\mathrm{TM}}$, ,

'Cavendish', 'Sable', and 'Kent' were the top yielding cultivars after Winter 20062007. During Winter 2005-2006, with 20 to $30 \mathrm{~cm}$ snow cover throughout the season, the 5 - and $10-\mathrm{cm}$ soil temperatures remained constant at $\approx 30$ to $31.5{ }^{\circ} \mathrm{F}$ in both mulched and unmulched treatments. In contrast, during Winter 2006-2007, there were 16 and 24 days (consecutive) in February below $18^{\circ} \mathrm{F}$ at $5-\mathrm{cm}$ soil depths for mulched and unmulched treatments, respectively, which probably led to the severe winter damage. Although straw mulch afforded the plants some protection, snow cover is critical to the survival of strawberries in northern Minnesota and other areas with similar weather conditions.

trawberry is an important and popular fruit throughout the world. In northern regions of Europe and North America, cold

We thank Drs. Neil Anderson and Eric Watkins for their critical review of the manuscript and also thank Dr. Joan Davenport, Dr. Neal De Vos, and three anonymous reviewers for their comments and suggestions to the previous version of this manuscript. We acknowledge Pat Johnson and Keith Mann for their assistance in this study.

${ }^{1}$ Department of Horticultural Science, University of Minnesota, St. Paul, MN 55108

${ }^{2}$ University of Minnesota, North Central Research and Outreach Center, 1861 East Highway 169, Grand Rapids, MN 55744

${ }^{3}$ Professor Emeritus.

${ }^{4}$ Corresponding author. E-mail: yaos@umn.edu. weather is a critical limiting factor for strawberry production (Boyce and Heleba, 1994; Linden et al., 2002; Nestby and Bjorgum 1999; Turner et al., 1993; Warmund and Ki, 1992). Winter mulch is usually applied and researchers have evaluated the effectiveness of different mulching materials on strawberry winter survival (Boyce and Heleba, 1994; Nestby et al., 2000). However, cold hardiness is a characteristic that is not as easily tested as productivity; therefore, some released cultivars have unknown cold hardiness, posing a risk for cold-climate growers. Different kinds of artificial freezing test methods have been used to predict strawberry cold hardiness (Linden et al., 2002; Warmund and $\mathrm{Ki}, 1992$ ). In vitro strawberry plant cold hardiness did not correlate well with field hardiness (Palonen and Buszard, 1997; Rugienius and Stanys, 1997). Also, runners from elite virus-free plants and those from commercial fields did not show consistent differences in cold hardiness, either in controlled freezing tests or field evaluations (Palonen and Linden, 2001). Field survival under conditions that cause differential injury among cultivars is the ultimate test of strawberry winter hardiness (Linden et al., 2002). The University of Minnesota North Central Research and Outreach Center at Grand Rapids, MN, is located in U.S. Department of Agriculture (USDA) plant hardiness zone 3b (Cathy, 1990), which makes it an ideal location for the cold hardiness evaluation of horticultural crops (Anderson et al., 2008; Luby et al., 2001, 2003). The objective of our research was to test the relative cold hardiness and performance of 15 strawberry cultivars in the field after Winter 2005-2006 and a test Winter 2006-2007, which had no snow cover until late Feb. 2007.

\section{Materials and methods}

This experiment was part of our hardy strawberry breeding/evaluation program at the University of Minnesota North Central Research and Outreach Center at Grand Rapids (lat. $47^{\circ} 14^{\prime} 33.39^{\prime \prime} \mathrm{N}$, long. $93^{\circ} 29^{\prime} 30.97^{\prime \prime} \mathrm{W}$, USDA plant hardiness zone $3 \mathrm{~b})$. Fifteen cultivars were

\begin{tabular}{llll}
\hline $\begin{array}{l}\text { Units } \\
\text { To convert U.S. to SI, } \\
\text { multiply by }\end{array}$ & U.S. unit & SI unit & $\begin{array}{l}\text { To convert SI to U.S., } \\
\text { multiply by }\end{array}$ \\
\hline 0.3048 & $\mathrm{ft}$ & $\mathrm{m}$ & 3.2808 \\
2.54 & inch(es) & $\mathrm{cm}$ & 0.3937 \\
0.4536 & $\mathrm{lb}$ & $\mathrm{kg}$ & 2.2046 \\
4.8824 & $\mathrm{lb} / \mathrm{ft}^{2}$ & $\mathrm{~kg} \cdot \mathrm{m}^{-2}$ & 0.2048 \\
28.3495 & $\mathrm{OZ}$ & $\mathrm{g}$ & 0.0353 \\
$\left({ }^{\circ} \mathrm{F}-32\right) \div 1.8$ & ${ }^{\circ} \mathrm{F}$ & ${ }^{\circ} \mathrm{C}$ & $\left(1.8 \times{ }^{\circ} \mathrm{C}\right)+32$
\end{tabular}


included in a randomized complete block design with three replications (Luby et al., 2001, 2003). Bare-root plants were used for all cultivars in this experiment from a single U.S. nursery except 'AC Wendy', which was supplied by a Canadian nursery under the experimental number 'KRS-02'. Each plot consisted of two subplots of six plants initially established in 2005 at 18 inches within rows and $4 \mathrm{ft}$ between rows and allowed to form matted rows. Subplots were separated in the row by $4 \mathrm{ft}$. One subplot in each plot was mulched for the winter and the other remained unmulched. Approximately 4 inches of wheat straw was applied on top of mulched plants in mid-November and removed and placed between rows in late April, depending on weather conditions. At the time of mulch removal in the spring, mulch was placed around plants in unmulched plots so that all plants benefited from mulch during the growing season. Fruit was harvested in 2006 and 2007. Total yield was recorded in each subplot, and the mean berry weight at each harvest was estimated using a sample of 25 berries. Each year, plant stand (percent leaf coverage for the designated area for each plot) was visually estimated in the fall before mulching and in the summer during picking season (Luby et al., 2001, 2003). Plants were renovated through flame-burning of old leaves and narrowing down the plots by tilling after harvest in July 2006 (Wildung, 2000). Because this trial is part of our strawberry breeding selection/ cultivar evaluation project, no destructive data were taken with these plants. Pesticide was used to control tarnished plant bugs (Lygus lineolaris) each year. No other pesticide or fungicide was used in this experiment. Overhead irrigation was supplied as necessary during the growing seasons but was not used to provide frost protection. Air and soil temperatures were recorded throughout the Winter 2005-2006 and Winter 2006-2007 with four-channel data loggers (HOBO; Onset Computer, Bourne, MA) with two replicates in each of the mulched and unmulched treatments for air, ground, and 5- and 10-cm soil temperatures.

Analyses of variance for plant stand, yield, and berry size were conducted separately for each of the 2 years of the trial for mulched and unmulched treatments with Statistix software (Analytical Software, Tallahassee, FL).

\section{Results and discussion}

ENVIRONMENTAL CONDITIONS. Soil temperatures were much colder in 2007 than in 2006 (Fig. 1A-B). During Jan. and Feb. 2007, daily minimum soil temperatures, on average, were $5.4^{\circ} \mathrm{F}$ lower in unmulched than in mulched plots. On 16 Jan. 2007, the soil temperature at $5-\mathrm{cm}$ soil depth reached $6.6{ }^{\circ} \mathrm{F}$ in unmulched plot and $20.6{ }^{\circ} \mathrm{F}$ in the mulched plot (Fig. 1B). The daily minimum soil temperatures in Feb.
2007 stayed below $18^{\circ} \mathrm{F}$ at 5 -cm soil depths for 16 and $24 \mathrm{~d}$ (consecutive) for mulched and unmulched treatments, respectively, which probably led to the severe winter damage observed in the Spring and Summer 2007 (Fig. 2; Table 1). There was almost no snow coverage until late Feb. 2007, so during the cold periods of January and early February, plants had no insulation afforded by snow. During the same period in 2006, the average snow coverage was 8 to 12 inches. The 5- and $10-\mathrm{cm}$ soil temperatures remained constant at $\approx 30$ to $31.5^{\circ} \mathrm{F}$ with $28^{\circ} \mathrm{F}$ being the lowest temperature recorded on both mulched and unmulched treatments
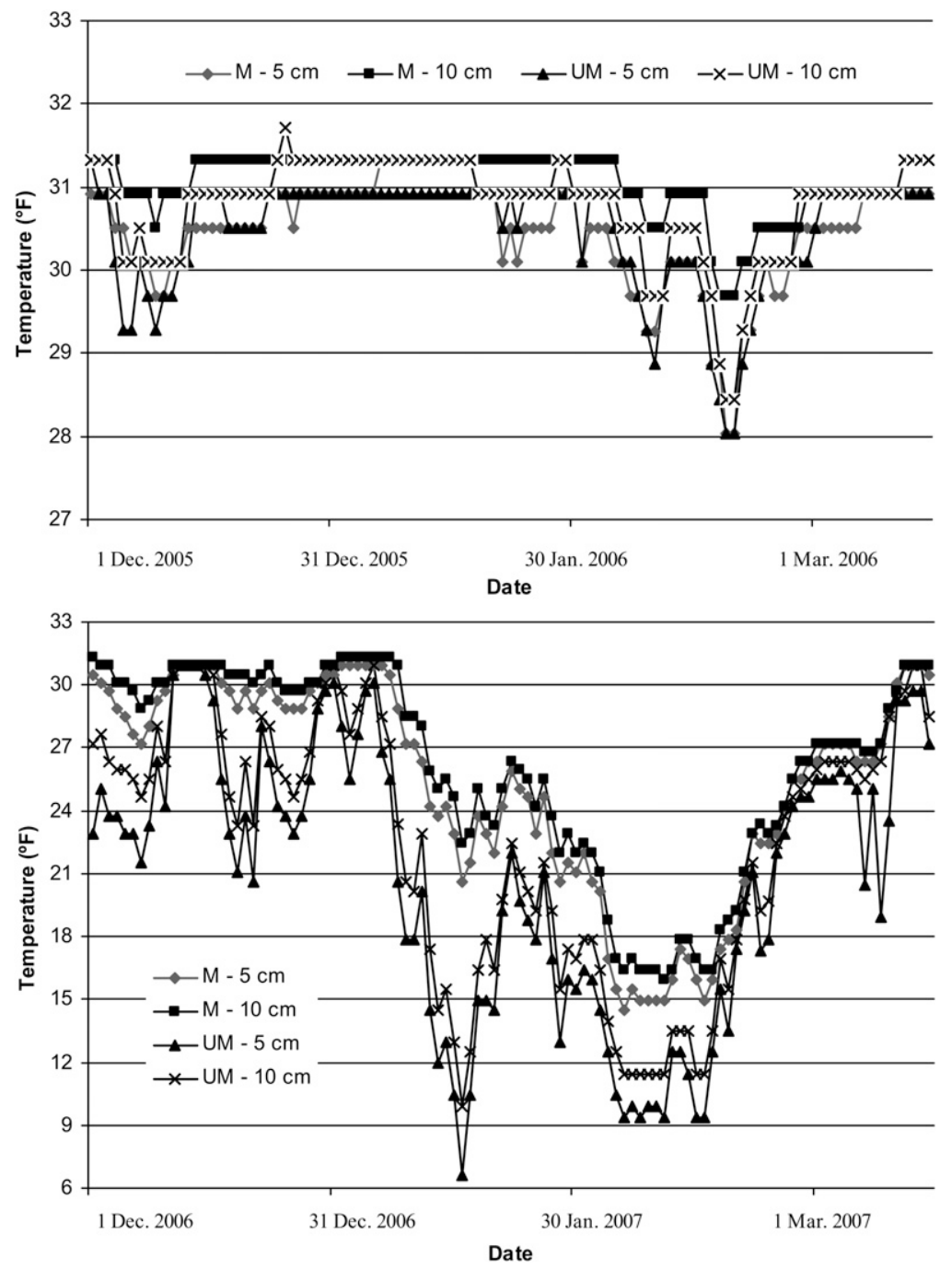

Fig. 1. Minimum soil temperatures at 5- and 10- $\mathrm{cm}$ (2.0 and 3.9 inches) soil depths for mulched (M) and unmulched (UM) strawberry plots during Winter 2005-2006 and 2006-2007 at Grand Rapids, MN (USDA plant hardiness zone 3b). To show the treatment temperature differences during Winter 2005-2006, (A) the y-axis ranged from 27 to $33{ }^{\circ} \mathrm{F}$; much narrower than the $\mathrm{y}$-axis $(\mathrm{B})$, which ranged from 6 to $33{ }^{\circ} \mathrm{F} ;\left({ }^{\circ} \mathrm{F}-32\right) \div 1.8={ }^{\circ} \mathrm{C}$. 

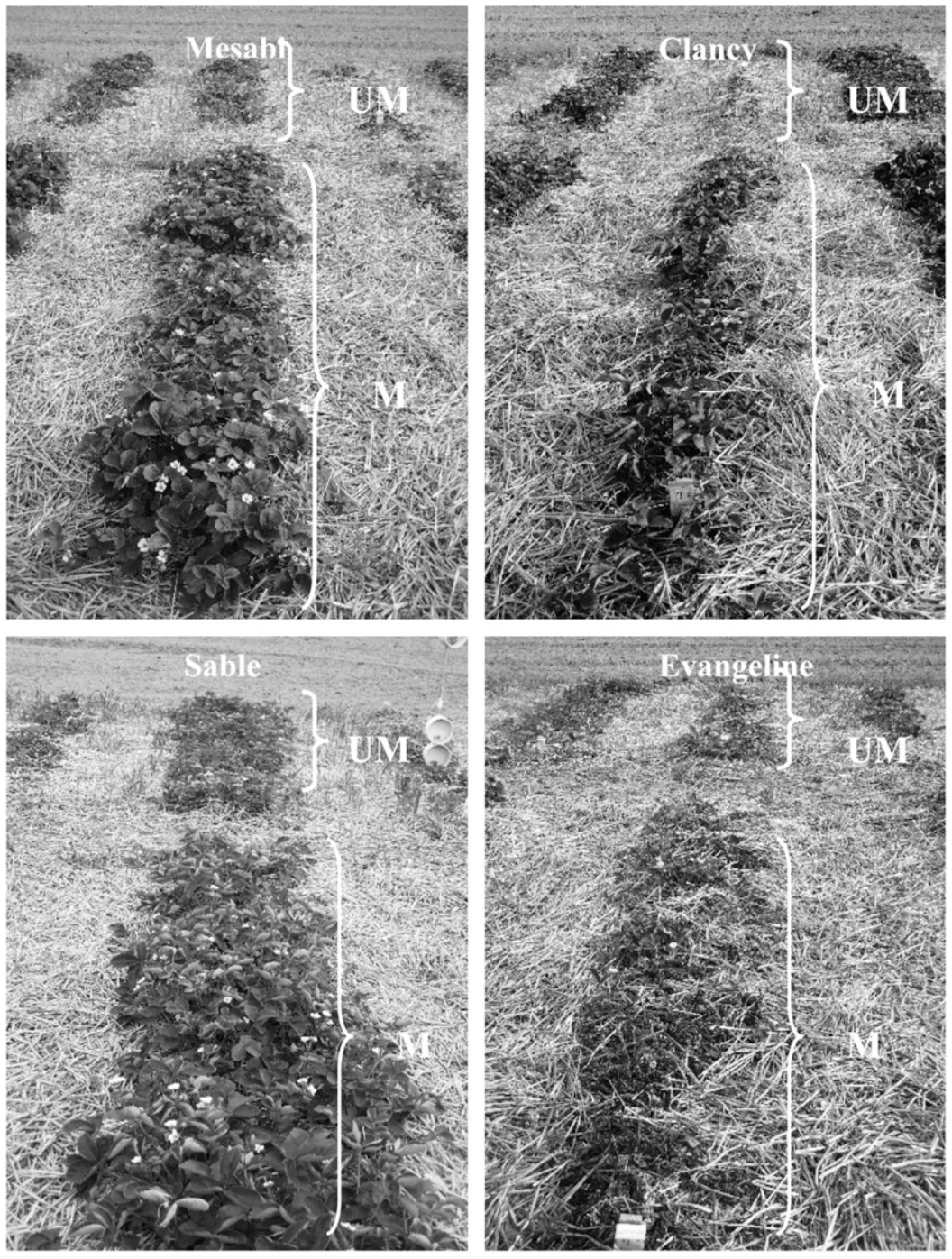

Fig. 2. Strawberry cultivars (Mesabi ${ }^{\mathrm{TM}}$, Clancy, Sable, and Evangeline) with varied winter survival in mulched (M) and unmulched (UM) plots after the test Winter 2006-2007 at Grand Rapids, MN (USDA plant hardiness zone 3b).

during Winter 2005-2006 (Fig. 1A). During sunny days from 9 Mar. to 13 Mar. 2007, the highest air temperatures were between 50 and $60^{\circ} \mathrm{F}$, but the temperatures on the ground surface and at 5 - and $10-\mathrm{cm}$ depths in the soil were $\approx 30$ to $31^{\circ} \mathrm{F}$. At Grand Rapids, MN (USDA plant hardiness zone $3 \mathrm{~b}$ ), temperature fluctuation may play a role in strawberry winter injury. However, more importantly, the depth and duration of cold temperatures in midwinter were critical factors affecting strawberry winter survival, especially during an open winter without snow cover.

Plant stand. All cultivars runnered well in 2005 to establish plots except 'AC Wendy', 'Winona ${ }^{\mathrm{TM}}$, and 'Annapolis' as a result of the quality of the original plants (Table 1; Fig. 2).
The plant stand of most cultivars after Winter 2005-2006 increased for mulched plots and unmulched plots and decreased slightly only for several cultivars in the unmulched plots. Compared with the unmulched treatment, the mulched treatment had a higher increase in stand rating at $7.8 \%$ versus $2.4 \%$ in the unmulched treatment after Winter 2005-2006. After Winter 2006-2007, the plant stand of all cultivars had drastically decreased in both mulched plots and unmulched plots. 'L'Amour', 'Evangeline', and 'Clancy' had higher strawberry plant stand reduction than 'Sable', 'Brunswick', 'Mesabi ${ }^{\mathrm{TM}}$, and 'Annapolis' after Winter 2006-2007 (Table 1). The stand ratios of 'Evangeline' and 'Clancy' were also lower than 'Cavendish', 'Kent', 'Glooscap', and 'Honeoye' (Table 1). Only several plants of 'Clancy' survived in the unmulched plots after Winter 20062007. After the Winter 2005-2006, June stand ratings of 'L'Amour', 'Evangeline', and 'Clancy' were as high as 'Sable', 'Brunswick', and 'Mesabi ${ }^{\text {TM' }}$ (Table 1). Unlike Winter 2005-2006, mulched and unmulched treatments showed similar plant stand reduction after Winter 2006-2007. 'L'Amour' was badly affected in early spring but later exhibited a better recovery in 2007. Shokaeva (2008) studied the winter damage of crown, branched crown, and root system of various genotypes and identified different strategies to survive the cold winter. Because we did not collect similar destructive data on this set of cultivars, further investigation is needed to confirm whether injury avoidance strategies vary among these 15 cultivars.

Linden et al. (2002) reported that freezing tests at $-6^{\circ} \mathrm{C}\left(21.2^{\circ} \mathrm{F}\right)$ for $26 \mathrm{~d}$ could distinguish some selections as less hardy than others, but no strawberry crown could survive $-8^{\circ} \mathrm{C}$ $\left(17.6^{\circ} \mathrm{F}\right)$ even for $\mathrm{l} \mathrm{d}$. Boyce and Heleba (1994) reported $-5{ }^{\circ} \mathrm{C}(23.0$ ${ }^{\circ} \mathrm{F}$ ) crown temperature as the crown injury threshold. Palonen and Linden (2001) stated that strawberry crowns could survive $-8{ }^{\circ} \mathrm{C}$ without injury but suffered severe injury when exposed to $-12{ }^{\circ} \mathrm{C}\left(-10.4^{\circ} \mathrm{F}\right)$ for $\mathrm{l} \mathrm{h}$. We could not determine the temperature threshold in this experiment; however, minimum temperatures below $18{ }^{\circ} \mathrm{F}$ at $5-\mathrm{cm}$ soil depth for more than half a month were definitely lethal to all strawberry cultivars. The daily minimum ground temperature (an estimate of crown temperature) was below $23{ }^{\circ} \mathrm{F}$ from 10 Jan. to 24 Feb. 2007 for both mulched plots and unmulched plots.

YIELD. On average, yields were reduced in 2007 compared with 2006 by $56 \%$ and $38 \%$ in mulched plots and unmulched plots, respectively (Table 2). 'Brunswick', 'Mesabi ${ }^{\mathrm{TM}}$,', 'Kent', and 'Cavendish' were the four highestyielding cultivars for both 2006 and 2007 in the mulched plots (Table $2)$. In the unmulched plots, 'Brunswick', 'Mesabi ${ }^{\mathrm{TM}}$, and 'Cavendish' were the top three high-yielding cultivars after Winter 2006-2007. 'Evangeline', 'Clancy', and 'AC Wendy' were always among the bottom cultivars for crop yield (Table 2) 
Table 1. Strawberry plant stand (percent leaf coverage of the designated plot area) changes of 15 cultivars observed in 2006 and 2007 for both unmulched and mulched plots at Grand Rapids, MN (USDA plant hardiness zone $3 \mathrm{~b}$ ). ${ }^{\mathrm{z}}$

\begin{tabular}{|c|c|c|c|c|c|c|}
\hline \multirow[b]{3}{*}{ Cultivar } & \multicolumn{3}{|c|}{ Unmulched } & \multirow[b]{3}{*}{ Cultivar } & \multicolumn{2}{|c|}{ Mulched } \\
\hline & \multirow{2}{*}{$\begin{array}{c}\text { June } 2007: \text { Oct. } \\
2006 \text { (ratio) }\end{array}$} & June 2007 & June 2006 & & June 2007 & June 2006 \\
\hline & & \multicolumn{2}{|c|}{ Plant stand ( $\%$ coverage) } & & \multicolumn{2}{|c|}{ Plant stand $(\%$ coverage $)$} \\
\hline Brunswick & 0.55 & 45.0 & 94.0 & Brunswick & 48.3 & 94.7 \\
\hline Mesabi $^{\mathrm{TM}}$ & 0.54 & 31.7 & 79.7 & Honeoye & 46.7 & 98.0 \\
\hline Annapolis & 0.53 & 21.7 & 61.7 & Glooscap & 43.3 & 91.7 \\
\hline Glooscap & 0.46 & 26.7 & 76.7 & Kent & 40.0 & 95.0 \\
\hline Honeoye & 0.37 & 30.0 & 91.7 & Mesabi $^{\mathrm{TM}}$ & 35.7 & 88.3 \\
\hline Jewel & 0.35 & 23.3 & 95.0 & Jewel & 33.3 & 95.0 \\
\hline $\mathrm{Itasca}^{\mathrm{TM}}$ & 0.35 & 24.0 & 93.0 & Annapolis & 28.3 & 85.0 \\
\hline Winona $^{\mathrm{TM}}$ & 0.34 & 12.0 & 73.3 & L'Amour & 23.3 & 96.3 \\
\hline AC Wendy & 0.28 & 14.3 & 35.7 & Winona $^{\mathrm{TM}}$ & 18.0 & 86.7 \\
\hline $\operatorname{LSD}^{\mathrm{y}}$ & 0.26 & 14.8 & 17.5 & LSD & 16.9 & 13.1 \\
\hline Avg & 0.382 & 25.1 & 84.2 & Avg & 33.1 & 90.5 \\
\hline
\end{tabular}

${ }^{2}$ The plant stand ratio of June 2007:Oct. 2006 is an indicator of plant survival over Winter 2006-2007.

'Fisher's protected least significant difference at $P \leq 0.05$.

LSD = least significant difference.

Table 2. Strawberry yield in 2006 and 2007 for both mulched and unmulched treatments at Grand Rapids, MN (USDA plant hardiness zone $3 b) .^{z}$

\begin{tabular}{|c|c|c|c|c|c|c|c|c|}
\hline \multirow[b]{2}{*}{ Cultivar } & \multicolumn{2}{|c|}{$\begin{array}{c}\text { Unmulched } \\
(1 \mathrm{~b} / \text { plot })^{\mathrm{y}}\end{array}$} & \multirow[b]{2}{*}{ Cultivar } & \multicolumn{2}{|c|}{$\begin{array}{r}\text { Mulched } \\
(1 \mathrm{~b} / \text { plot }) \\
\end{array}$} & \multirow[b]{2}{*}{ Cultivar } & \multicolumn{2}{|c|}{$\begin{array}{c}\text { Unmulched + } \\
\text { mulched (lb/plot) }\end{array}$} \\
\hline & 2007 & 2006 & & 2007 & 2006 & & 2007 & 2006 \\
\hline Mesabi $^{\mathrm{TM}}$ & 4.53 & 3.10 & Mesabi $^{\mathrm{TM}}$ & 8.53 & 14.72 & Mesabi $^{\mathrm{TM}}$ & 6.53 & 8.91 \\
\hline Cavendish & 4.07 & 4.88 & Kent & 7.97 & 15.30 & Kent & 5.30 & 10.21 \\
\hline Sable & 2.67 & 2.25 & Cavendish & 5.70 & 12.70 & Cavendish & 4.88 & 8.79 \\
\hline Honeoye & 1.80 & 4.69 & Itasca $^{\mathrm{TM}}$ & 4.13 & 10.83 & Itasca $^{\mathrm{TM}}$ & 2.97 & 7.88 \\
\hline Itasca $^{\mathrm{TM}}$ & 1.80 & 4.94 & Glooscap & 3.70 & 9.53 & Jewel & 2.73 & 8.37 \\
\hline L'Amour & 1.53 & 2.19 & Jewel & 3.13 & 10.90 & Glooscap & 2.60 & 5.86 \\
\hline Glooscap & 1.50 & 2.20 & Annapolis & 3.00 & 4.73 & Annapolis & 1.80 & 2.94 \\
\hline Winona $^{\text {TM }}$ & 0.83 & 4.35 & L'Amour & 1.93 & 7.32 & L'Amour & 1.73 & 4.75 \\
\hline $\operatorname{LSD}^{\mathrm{x}}$ & 2.54 & 2.82 & LSD & 4.48 & 4.26 & LSD & 2.52 & 2.72 \\
\hline Avg & 2.05 & 3.31 & Avg & 4.03 & 9.19 & Avg & 3.04 & 6.25 \\
\hline
\end{tabular}

${ }^{\mathrm{z}}$ Unmulched and mulched treatments and each year were calculated separately.

${ }^{y} 1 \mathrm{lb} /$ plot $=0.1221 \mathrm{~kg} \cdot \mathrm{m}^{-2}$; plot size was $10 \times 4 \mathrm{ft}(3.05 \times 1.22 \mathrm{~m})$.

'Fisher's protected least significant difference at $P \leq 0.05$

LSD $=$ least significant difference.

and were significantly lower in yield than the top four performing cultivars, Brunswick, Mesabi ${ }^{\mathrm{TM}}$, Kent, and Cavendish, in all treatments and for all seasons. The low vields of 'AC Wendy' and 'Winona ${ }^{\text {TM, }}$ could be partially the result of the poor establishment in 2005; however, the
June 2006 stand ratings for 'Evangeline' and 'Clancy' were among the highest of all 15 cultivars. 'Clancy' performed well in mulched plots after the mild winter but showed extensive mortality in the unmulched plots after the severe test of Winter 20062007.
Winter straw mulch application affected yield after the snow-covered Winter 2005-2006. Although the plant stand counts were similar for most cultivars between mulched plots and unmulched plots, the average yield of mulched plots was $175 \%$ higher than the yield of unmulched 
plots. This significant difference in yield was not the result of protection from mulch in midwinter, but was likely the result of a several-day delay in phenological development of mulched plots, which allowed those plants to avoid a late frost on 21 May 2006. No frost protection technique was used in this experiment. Later, during bloom, we observed that the receptacles of primary flowers in unmulched plots had been killed and turned black. This damage also explained why the yield reduction percentage in 2007 was less in unmulched plots than mulched plots. Boyce and Heleba (1994) observed that after heavy snow-covered winters, strawberries produced the highest yields and largest fruits with no yield difference observed as a result of whether or not the plants were mulched. Other strawberry cultivar trials we have conducted have showed similar results (data not shown). After snow-covered winters, unmulched plots produced similar or higher yields than mulched plots in 2004, 2005 , and 2008. The low yield of unmulched plots in 2006 was the result of the severe late frost after the snow-covered Winter 20052006.

Berry weight. The average berry weight was 13.4 and $10.9 \mathrm{~g}$ in 2006 and 9.9 and $7.1 \mathrm{~g}$ in 2007 in mulched and unmulched plots, respectively (Table 3 ). Fruit size is determined in part by genetic factors, but also varies with environmental conditions such as midwinter stress, frost injury, precipitation, and pest damage. In 2006, the late frost damaged the primary berries mainly in the unmulched plots. This decreased the average berry size compared with the mulched plots, especially for those early cultivars. In 2007, the small berry size for all cultivars was mainly the result of the midwinter damage.

\section{Conclusion}

Based on this report, 'Brunswick', 'Cavendish', 'Kent', 'Mesabi ${ }^{\mathrm{TM}}$, and 'Sable' were the top five performing cultivars among the 15 tested. On the other hand, 'Clancy', 'Evangeline', 'AC Wendy', and 'L'Amour' were the most cold-sensitive cultivars. The performance of 'AC Wendy' may also reflect the quality of planting stock, which did not appear as vigorous or develop as dense a stand as the other cultivars during the 2005 establishment year. Yield and survival rates from this trial confirm the growers' adoption of 'Kent', 'Cavendish', and 'Mesabi' ${ }^{\mathrm{TM}}$, over the other cultivars for climates and sites with the potential for open cold winters.

Although we did not determine the temperature threshold for injury,

Table 3. Strawberry mean fruit weight in 2006 and 2007 in mulched and unmulched plots at Grand Rapids, MN (USDA plant hardiness zone $3 b$ ). ${ }^{z}$

\begin{tabular}{|c|c|c|c|c|c|}
\hline \multirow[b]{2}{*}{ Cultivar } & \multicolumn{2}{|c|}{$\begin{array}{l}\text { Unmulched } \\
\text { (g/berry })^{\mathrm{y}}\end{array}$} & \multirow[b]{2}{*}{ Cultivar } & \multicolumn{2}{|c|}{$\begin{array}{l}\text { Mulched } \\
\text { (g/berry) }\end{array}$} \\
\hline & 2007 & 2006 & & 2007 & 2006 \\
\hline L'Amour & 9.32 & 13.73 & Clancy & 13.85 & 16.92 \\
\hline Cavendish & 8.81 & 13.00 & L'Amour & 12.42 & 17.40 \\
\hline Brunswick & 8.13 & 10.85 & Cavendish & 11.94 & 14.81 \\
\hline Jewel & 8.13 & 11.84 & Brunswick & 11.43 & 13.09 \\
\hline Clancy & 7.63 & 14.29 & Kent & 11.16 & 13.03 \\
\hline Winona $^{\mathrm{TM}}$ & 7.39 & 11.73 & Jewel & 10.38 & 13.81 \\
\hline Mesabi $^{\mathrm{TM}}$ & 7.35 & 9.94 & Winona $^{\mathrm{TM}}$ & 10.23 & 13.94 \\
\hline Annapolis & 7.27 & 10.91 & Mesabi $^{\mathrm{TM}}$ & 9.68 & 12.77 \\
\hline AC Wendy & 7.25 & 9.75 & Annapolis & 9.63 & 13.31 \\
\hline Itasca $^{\mathrm{TM}}$ & 6.66 & 11.05 & Glooscap & 8.98 & 11.95 \\
\hline Kent & 6.52 & 9.68 & Itasca $^{\mathrm{TM}}$ & 8.92 & 13.17 \\
\hline Sable & 6.01 & 8.37 & Sable & 8.60 & 10.16 \\
\hline Glooscap & 5.41 & 9.07 & AC Wendy & 8.21 & 13.55 \\
\hline Evangeline & 5.04 & 8.51 & Honeoye & 7.72 & 11.50 \\
\hline Honeoye & 5.00 & 10.45 & Evangeline & 5.44 & 11.73 \\
\hline LSD $^{x}$ & 2.44 & 2.28 & LSD & 3.70 & 2.02 \\
\hline Avg & 7.06 & 10.88 & Avg & 9.91 & 13.41 \\
\hline
\end{tabular}

${ }^{2}$ Each treatment and year was analyzed separately.

${ }^{y} \mathrm{l} g=0.0353 \mathrm{oz}$.

'Fisher's protected least significant difference at $P \leq 0.05$. this study provides useful information for strawberry growers or breeders in cold areas regarding the relative cold hardiness of the cultivars and the limitations of the mitigating effects of snow and straw mulch. A minimum snow cover of 6 to 8 inches would make the strawberry plants safe for most winters; however, snow cover is not reliable from year to year. In a severe winter like 2006-2007 with no snow cover, 4 inches of straw mulch provided the strawberry plants some protection, but not enough to avoid substantial injury when soil temperatures reached below $18{ }^{\circ} \mathrm{F}$ for an extended period of time.

\section{Literature cited}

Anderson, N., P. Ascher, E. Gesick, L. Klossner, N. Eash, V. Fritz, J. Hebel, S. Poppe, J. Reith-Rozelle, R. Wagner, S. Jacobson, D. Wildung, and P. Johnson. 2008. Winter-hardy Mammoth ${ }^{\text {TM }}$ series garden chrysanthemums 'Red Daisy,' 'White Daisy,' and 'Coral Daisy' sporting a shrub plant habit. HortScience 43:648-654.

Boyce, B.R. and D.A. Heleba. 1994. Comparison of several mulching systems for winter injury protection and yield of 'Midway' strawberry plants. Adv. Strawberry Res. 13:32-35.

Cathy, H.M. 1990. USDA plant hardiness zone map. U.S. National Arboretum, Agr. Res. Serv., U.S. Dept. Agr. Misc. Publ. No. 1475.

Linden, L., P. Palonen, and T. Hytonen. 2002. Evaluation of three methods to assess winter-hardiness of strawberry genotypes. J. Hort. Sci. Biotechnol. 77:580588.

Luby, J.J., D.K. Wildung, and G.J. Galletta. 2001. MNUS 210 (Winona ${ }^{\mathrm{TM}}$ ) strawberry. HortScience 36:392-394.

Luby, J.J., D.K. Wildung, and G.J. Galletta. 2003. 'MNUS 248' (Mesabi ${ }^{\mathrm{TM}}$ ) strawberry. HortScience 38:481-483.

Nestby, R. and R. Bjorgum. 1999. Freeze injury to strawberry plants as evaluated by crown tissue browning, regrowth ad yield parameters. Scientia Hort. 81:321329.

Nestby, R., R. Bjorgum, A. Nes, R. Wikdahl, and B. Hageberg. 2000. Winter cover affecting freezing injury in strawberry in a coastal and continental climate. J. Hort. Sci. Biotechnol. 75:119-125.

Palonen, P. and D. Buszard. 1997. Screening strawberry cultivars for cold hardiness in vitro. Acta Hort. 439:217220 . 


\section{Preliminary and Regional Reports}

Palonen, P. and L. Linden. 2001. Winter hardiness of micropropagated and conventionally propagated strawberry plants. J. Hort. Sci. Biotechnol. 76:685-690.

Rugienius, R. and V. Stanys. 1997. In vitro screening of cold resistant strawberry cultivars and seedlings. Acta Hort. 439:221-226.

Shokaeva, D.B. 2008. Injuries induced in different strawberry genotypes by winter freeze and their effect on subsequent yield. Plant Breed. 127:197-202.

Turner, J.M., K.K. Tanino, and C. Stushnoff. 1993. Evaluation of low temperature hardiness of strawberry plants under field and controlled conditions Can. J. Plant Sci. 73:1123-1125.

Warmund, M. and W.K. Ki. 1992. Fluctuating temperatures and root moisture content affect survival and regrowth of cold-stressed strawberry crowns. Adv. Strawberry Res. 11:40-45.

Wildung, D.K. 2000. Flame burning for weed control and renovation with strawberries, p. 91-95. In: J. Cibrorowski (ed.). Greenbook 2000-Marketing sustainable agriculture. Minnesota Dept. Agr., St. Paul, MN. 